\title{
Copper isotope fractionation in volatile-fluxed enclaves: Modern analogues for the genesis of ancient ore deposits
}

\author{
LUCY MCGEE ${ }^{1 *}$, CHRISTOPHER LOWCZAK ${ }^{1}$, JURAJ
}

FARKAS $^{1}$, JUSTIN PAYNE ${ }^{2}$, CLAIRE WADE ${ }^{1,3}$ AND ANTHONY REID ${ }^{1,3}$

${ }^{1}$ University of Adelaide, Adelaide, Australia

(*correspondence: lucy.mcgee@adelaide.edu.au)

${ }^{2}$ University of South Australia, Adelaide, South Australia

${ }^{3}$ Geological Survey of South Australia, Adelaide, South

Australia

Mafic enclaves are a common feature of volcanic deposits and provide some of our best estimates of the material entering the plumbing system beneath volcanic edifices. Geochemical studies of enclaves in modern volcanic settings can be compared to ancient volcanic deposits where little is known about the tectonic history and magmatic inputs of the system. When applied to a region rich in critical minerals, such studies may provide important links between magmatic processes and genesis of economic deposits.

Mafic material has the potential to carry volatiles to the surface which may transport metal elements. Deep volatiles driven from the subducting slab also provide elemental enrichment to the mantle wedge beneath areas of potential magmatism, which could be an important precursor to ore forming magmas [1]. We compare the $\delta^{65} \mathrm{Cu}$ values of mafic material from ancient, mineralised terranes with modern active volcanic settings where processes and inputs are less ambiguous. We focus on the Mesoproterozoic Gawler Range Volcanics (GRV) of Southern Australia, a voluminous Silicic Large Igneous Province which contains mafic material in the form of minor basaltic lava flows and enclaves dispersed within dacites and rhyolites which range from $\delta^{65} \mathrm{Cu}-0.73$ to $+0.61 \pm 0.05$. Importantly, one of the world's most valuable Iron Oxide Copper Gold (IOCG) deposits, Olympic Dam, is associated with GRV magmatism at ca. $1590 \mathrm{Ma}$ [2]. We compare these new isotopic data with analyses of mafic enclaves erupted within andesitic material between $1995 \mathrm{AD}$ and $2010 \mathrm{AD}$ from Soufriere Hills Volcano, Montserrat which have chemical signatures suggestive of recent volatile fluxing from mafic recharge material [3].

[1] Skirrow, R., et al., 2018, G-cubed, 2018. 19(8): p. 26732705. [2] Reid, A., 2019, Minerals, 2019. 9(6): p. 371. [3] McGee et al., 2019, Earth Planet. Sci. Lett., 524, 115730 